ESJ Social Sciences

\title{
ISO 9001 Quality Approach and Performance Literature Review
}

\begin{abstract}
Echour Saida
(Phd Student in Management Science; Laboratory for Skills Management, Entrepreneurial Innovation and Social Aspects of Organization "GESIAS") Hassan II University/ Faculty of Economic and Social Juridical Sciences, Ain chock, Casablanca, Morocco

Nbigui Taibi

(Professor of Higher Education at the Superior School of Technology, Laboratory for Skills Management, Entrepreneurial Innovation and Social Aspects of Organization "GESIAS")

Hassan II University / Higher School of Technology, Casablanca, Morocco
\end{abstract}

Doi:10.19044/esj.2021.v17n1p128

Submitted: 31 August 2020

Accepted: 14 January 2021

Published: 31 January 2021
Copyright 2021 Author(s)

Under Creative Commons BY-NC-ND

4.0 OPEN ACCESS

Cite As:

Saida E. \& Taibi N. (2021). ISO 9001 Quality Approach and Performance Literature Review. European Scientific Journal, ESJ, 17(1), 128. https://doi.org/10.19044/esj.2021.v17n1p128

Abstract

In the face of changing economic conditions and tougher markets, organizations must increase their competitiveness, increase their flexibility and improve their performance. All now have performance and continuous improvement objectives. Management standards (ISO 9001) are often associated with heavy and procedural systems. On the contrary, they are powerful performance levers for certified organizations. ISO 9000 defines performance as a "measurable result" which is related to the activities, processes, product management (including services) systems or organizations. The purpose of this article is to review the literature on the relationship between quality approach and organization performance, a discussion on the quality practices and performance are presented and conceptual models are proposed.

Keywords: Quality management; Iso certification; Quality approach; Performance 


\section{Introduction}

Despite many years of the ISO 9001 certification of quality management systems around the world, experts still question the benefits and added value of this certification within organizations. This encourages the proliferation of academic research in this field (ISO 9001,2015). There is a great deal of research on quality management, but the results are far from being fruitful and do not provide clear confirmations of the positive or negative impact of this approach on organizations' performance, given that organizations are subject to the conditions for introducing certification (Rolland \& Tran, 2006). The impact of ISO 9001 certification on the organization's performance is a research component that attracts many researchers and drives them to unveil to professionals, reality on the impact of the ISO 9001 certification. In this context, this paper presents a literature review on the impact of the implementation of the quality management system on the company's performance.

The first part of this paper describes the concepts and principles of quality management, the second part deals with a literature review about the quality concepts and finally the summary of some research dealing with the link between the quality approach and performance. In the third part, we explain the construction of the conceptual model of the research highlighting the effect of the quality approach on performance.

\section{Literature review:}

This literature review consists of collecting, reading, analyzing, and synthesizing a scientific paper from 1980 to 2019, using keywords related to our research. The papers were extracted from a major peer-reviewed international journals and selected using a methodological process that combined electronic search and manual analysis. An electronic tool by "Google Scholar; database; specialized and generalist journals as well as handbooks and theses" were used to identify articles that papers associated with keywords related to the issue. Then, a detailed analysis of the references cited in the articles was carried out, to highlight the main advances in terms of theoretical scoping of the research objects (Dumez, 2011). The target is to look at how the topic of quality management and performance is defined in the literature, in order to define it, before starting a more in-depth research work on the subject. Based on this analysis, a conceptual research framework will be proposed.

\section{II.1 Definitions and concepts of quality management:}

The quality management system (QMS) is based on the basic principles that the organization must apply before starting the process of implementing the system in order to achieve certification. 


\section{II.1.1 Quality management system definitions:}

The quality management includes "the activities through which the organization identifies its objectives and determines the processes and resources needed to achieve the expected results. It is a set of interrelated or interacting elements of an organization, aimed to establish policies, objectives and processes in order to accomplish those objectives. These elements include the structure, roles and responsibilities, planning, operation of the organization, policies, practices, rules, convictions objectives and processes to reach these objectives" ( ISO 9001, 2015 ).

The International Organization for Standardization (ISO) is an independent non-governmental international organization, which brings together experts to combine their knowledge to develop voluntary, consensusbased, market-relevant international standards supporting innovation and providing solutions to global challenges (ISO, 2020).

The quality management certification according to the ISO 9001 standard is a third-party recognition that the company complies with the guidelines of that standard. It provides a guarantee that the company has a management system within its organization which meets the requirements of the standard.

The QMS (Figure 1) is the set of actions implemented by a company that aims to have a continuous improvement approach in order to increase the quality of its production and its organization for the purpose of its certification. It includes the activities by which the organization identifies its objectives and determines the processes and resources required to achieve the expected results. It covers all levels of the company's activities : communication, marketing, production, sales, human resources, logistics, etc.... (ISO 1005, 2005). 
Figure 1 : Model of a quality management system (ISO 10005:2005)

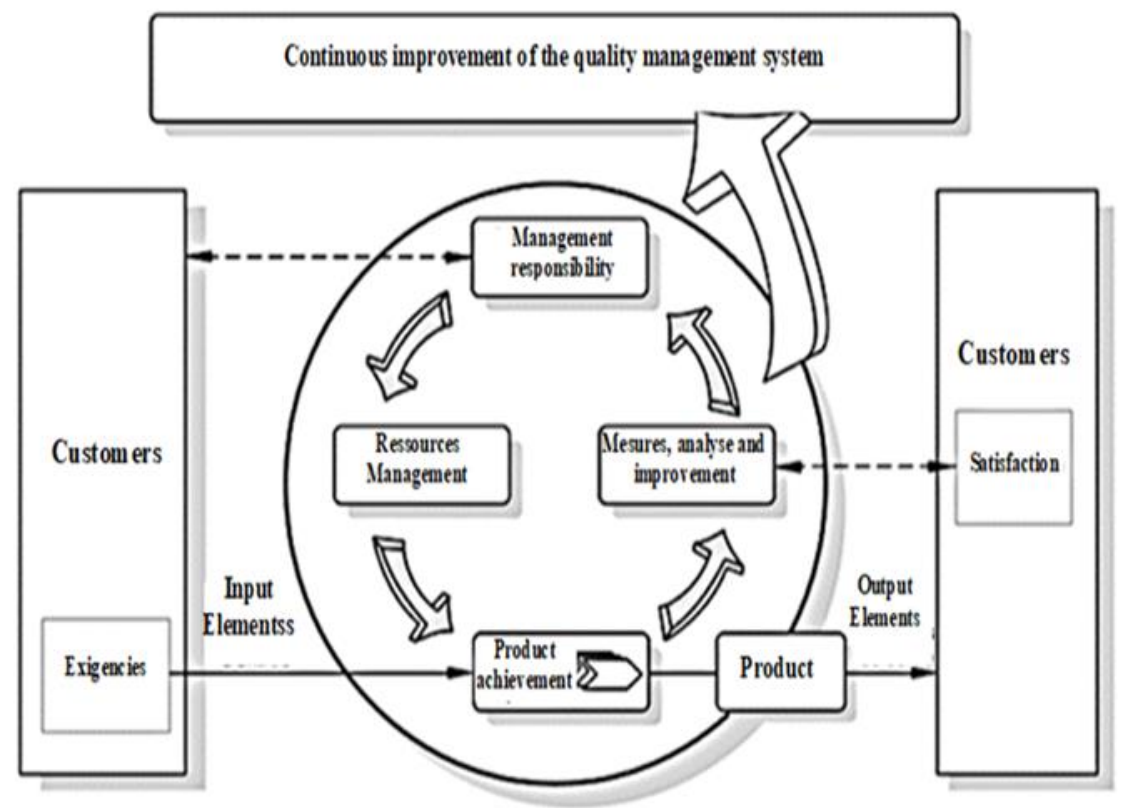

\section{II.1.2 Quality management principles:}

The Quality Management Principles (QMP) are a set of values, rules, standards and fundamental beliefs that are considered fair and likely to serve as a basis for quality management. The QMP can be used as a basis to guide the improvement of an organization's performance. They were developed and updated by the ISO/TC 176 international experts, responsible for the development and updating of ISO quality management standards (ISO, 2016). The QMP that companies must to adhere in order to meet the requirements of the ISO 9001 standard are:

- Customer Orientation: The main objective of quality management is to satisfy the requirements of customers, and to strive to exceed their expectations. This customer focus appears to be a fundamental concept of quality management, since organizations exist to provide goods and services to the customer (Juran and Godfrey, 1999). The organization should adopt a customer-oriented policy with the aim of realizing longterm capabilities and thus improve its performance (Pekovic and Rolland, 2012).

- Leadership: At all levels, leaders set purpose and directions and create conditions in which staff are involved to achieve the organization's quality objectives. Building quality leadership is often the result of an original quality that gains what marketers call "a previous franchise". 
Once acquired, this franchise can be maintained through continuous product improvement and effective promotion (Juran and Godfrey, 1999).

According to Maxwell (2011), there are five levels of leadership. At each level the leader's behaviors change, and this change has a significant impact on the results of achieving the objectives. At the first level, the leader acts based on his status, title and position in the company, association or team, etc... But this position is not enough to push people to follow, hence the need for level two leadership. Called the relationship-permission level, where people follow the leader by will, since that level is based on people's respect and appreciation (Maxwell, 2011). The third level, represents the results or output level through which people follow the leader, based on her results achieved in the organization. At this stage, people are true agents of change, make difficult decisions and contribute to achieving the set objectives. Subsequently, the fourth level of people development where leaders invest more in teamwork, to achieve a high level of efficiency and results is highlighted (Maxwell, 2011). The pinnacle of leadership is the five level, it is the summit where people follow the leader for who he is and for what he represents. At this level, the senior leader develops employees into level four leaders and designs a space to launch employees to the top (Maxwell, 2006).

- Staff involvement: Competent, empowered and engaged staff at all levels of the organization is essential to improve the organization's ability to create and deliver value. The staff involvement is a key element in the success of the organization. Their satisfaction is paramount and the company must give them a lot of attention to promote their involvement. This satisfaction is achieved through training and skills development as well as by means of participation in decision-making (Chaminade, 2005).

According to Iso 10018 version 2012, the staff involvement is a key process of strategic processes, which contributes to the deployment of the quality management principles and human factors development of the organization (ISO 10018:2012(fr), 2012).

- The process approach: Consistent and predictable results are more effectively and efficiently achieved when activities are understood and managed as correlated processes operating as a coherent system (Figure 2). It is a method of analysis and modelling, and its role is to work collectively on improving the organization's efficiency (Brandenburg and Wojtyna, 2003). 
Figure 2: The schematic representation of process elements (ISO 9001,2015)

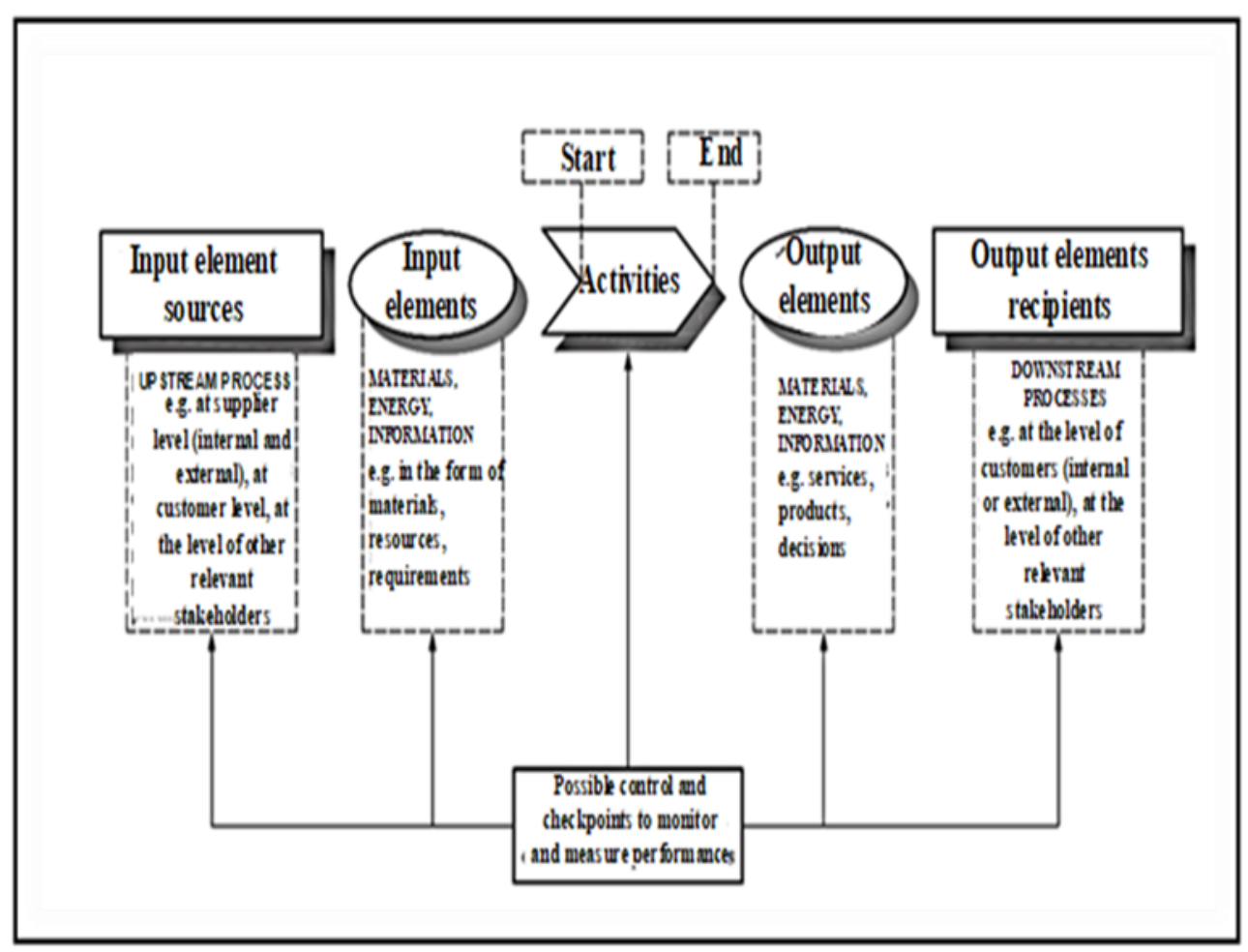

- Improvement: The success of an organization is based on a constant drive for improvement. This process is based on the Deming Wheel principles; following the PDCA cycle: Plan, Do, Check and Act (Figure 3). It is one of the fundamental quality management principles. The company should, first of all, plan its quality management system. On the basis of this planning the actions are implemented. Afterwards a post-implementation check is necessary. This audit would evaluate the effectiveness of the action. Thus, further actions can be triggered following the results of this evaluation, and will be in turn replanted according to the Deming Wheel principle.( ISO 9001, 2015). 
Figure 3: the Deming PDCA cycle and continuous improvement

(Deming \& Edwards, 1982).

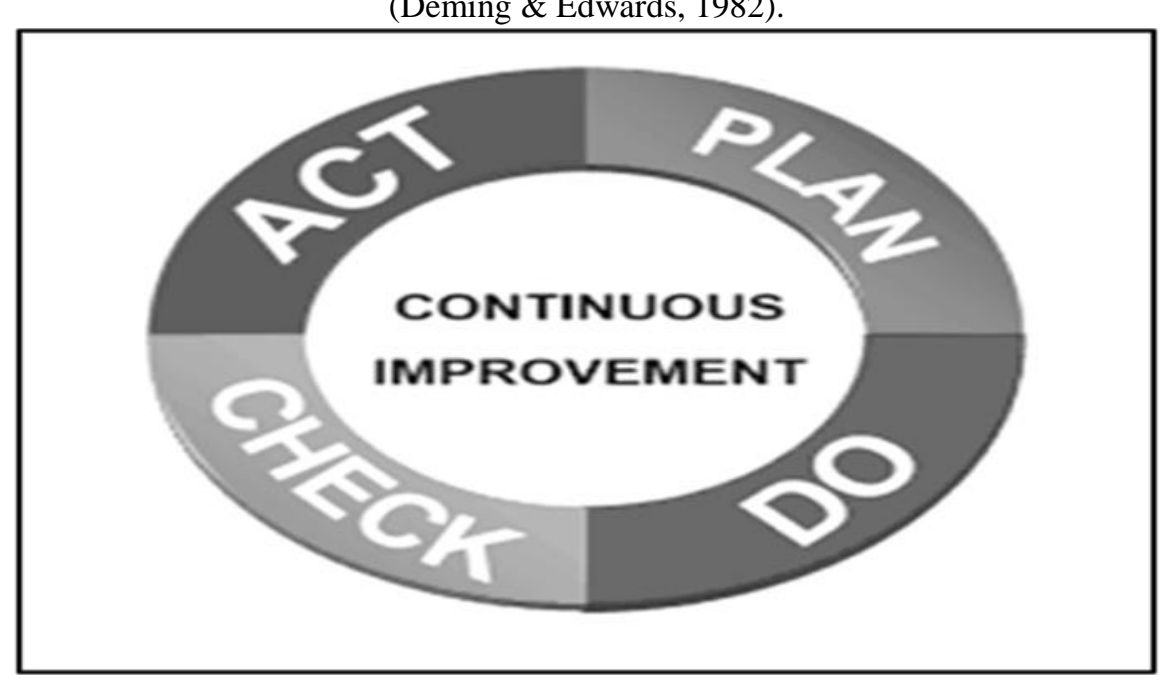

- Evidence-based decision-making: Decisions based on the analysis and data evaluation and information are more likely to produce the expected results. "What is asserted without evidence can be denied without evidence" (Qualitiso, 2014). It is a very Cartesian approach that is seductive if not labour intensive. The idea is to reduce the inevitable uncertainty in decision-making, based on objective data, where causes are examined to understand the effects (Qualitiso, 2014).

- Stakeholder relations management: To achieve sustainable performance, the organizations manage their relationships with interested parties also known as stakeholders. The principle of this type of management states that managers have ethical obligations toward their stakeholders (Mercier, 2006).

\section{II.2 Quality management practices:}

The quality management practices concern the voluntary activities carried out by the organization, in compliance with the requirements of the ISO 9001 standard, in order to improve its performance (Patyal \& Koilakuntla, 2017). The literature highlights the most critical or difficult practices to implement it for organizations. Since the quality management system is framed by the requirements of the ISO 9001 standard, the success factors of this system are globally inspired by the rigorous application of what is stipulated in its reference frame. The literature presents a panoply of quality approaches and practices that contribute to the successful implementation of this system within the organization. All these approaches and practices have a common source which is the ISO 9001 standard. The citation of all or some of 
these approaches in the literature generally depends on the study field and the specific context of each research.

According to Feng and al. (2008), the approaches which allow successful implementation of the quality management system are:

- System Implementation Planning: This planning includes a shortterm planning to achieve certification and long-term planning to support the initial effort involved during the certification preparation. The criteria for this planning are: the identification of quality aspects, documentation, training, investment and standard development procedures.

- Commitment: This is all levels involvement of the organization, the senior and middle management commitment, the employee commitment and the commitment of the trade union engagement.

- The implementation of procedures: or the application of procedures that stand out among the difficulties encountered by companies during the implementation and certification maintenance. The criteria are : Periodic audits, following standard procedures, implementation and certification maintenance (Feng, Terziovski, and Samson 2008).

In 2018, Fonseca and Domingues explored the ISO practices in 300 portuguese companies. They considered that the risk and opportunity-based thinking, determination of the organizational context with relevant the internal and external issues, identification of relevant stakeholders and their relevant requirements, organizational knowledge and change control are the main difficulties encountered by companies for the effective implementation of the quality system according to the ISO 9001 version 2015 standard (Fonseca and Domingues 2018).

The table 1 summarizes the different quality management practices according to the literature:

\begin{tabular}{|l|l|}
\hline Quality practices & Authors \\
\hline $\begin{array}{l}\text { Customer focus, } \\
\text { Continuous improvement, }\end{array}$ & (Pambreni et al., 2019) \\
Strategically based, & \\
Total employee involvement & \\
\hline $\begin{array}{l}\text { Thinking based on identification of risks and opportunities and } \\
\text { adopting risk-based thinking }\end{array}$ & (Fonseca and Domingues, 2018) \\
$\begin{array}{l}\text { Identifying the organizational context with relevant internal and } \\
\text { external issues }\end{array}$ & \\
Identification of the relevant stakeholders and their relevant \\
requirements; \\
$\begin{array}{l}\text { Organizational knowledge } \\
\text { change control }\end{array}$
\end{tabular}




\begin{tabular}{|c|c|}
\hline $\begin{array}{l}\text { the system implementation Planning } \\
\text { Commitment } \\
\text { Implementation of procedures }\end{array}$ & $\begin{array}{l}\text { (Feng, Terziovski and } \\
\text { Samson,2008) }\end{array}$ \\
\hline $\begin{array}{l}\text { Management practices: } \\
\text { - Senior management commitment and support. } \\
\text { Infrastructure practices: } \\
\text {-Quality organization } \\
\text { - Employee training } \\
\text { - Worker participation } \\
\text { - Supplier Quality Management } \\
\text { - Customer focus } \\
\text { - Ongoing support } \\
\text { The basic practices: } \\
\text { - quality system Improvement } \\
\text { - Information and analysis } \\
\text { - Use of statistical quality techniques } \\
\end{array}$ & $\begin{array}{l}\text { (Lakhal, Pasin, and Limam } \\
\text { 2006) }\end{array}$ \\
\hline $\begin{array}{l}\text { Leadership } \\
\text { Training } \\
\text { Relationship employee involvement } \\
\text { Product/service } \\
\text { Design } \\
\text { Supplier Quality Management } \\
\text { quality data analysis } \\
\text { Process management }\end{array}$ & (Kaynak, 2003) \\
\hline $\begin{array}{l}\text { Leadership } \\
\text { Strategic planning } \\
\text { Customer focus } \\
\text { Information and analysis } \\
\text { People management } \\
\text { Process management }\end{array}$ & (Prajogo \& Sohal, 2003) \\
\hline $\begin{array}{l}\text { Leadership and Commitment } \\
\text { Training and awareness } \\
\text { Team } \\
\text { Culture }\end{array}$ & (Reed et al., 2000) \\
\hline $\begin{array}{l}\text { Relationship with customers } \\
\text { Support for Senior management } \\
\text { Work force Management } \\
\text { Relationship with suppliers } \\
\text { Statistical control feedback } \\
\text { Process planning management } \\
\text { Product Design Process }\end{array}$ & (Flynn et al., 1995) \\
\hline
\end{tabular}

\section{II.3 Performance:}

The performance is seen as a multidimensional concept relating to the individuals who use it. Its concept differs from the point of view of manager, employee or customer, which makes it subjective and having several meanings (Salgado, 2013). Pesqueux (2004) refers to the notion of global performance as a materialization of organizational performance. He defines it as a 
numerical result of a classification objective in relation to a reference frame or measurement scale. This reference can be in relation to the oneself, to improve one's performance and/ or relates to others (Pesqueux, 2004).

The performance measurement is carried out on three axes, namely,

- Relevance: when relationship between the initial objectives and the resources acquired to achieve them,

- Efficiency: the relationship between the results obtained and the resources used,

- Effectiveness: the relationship between the results achieved and the initial objectives (Gilbert, 1980).

The performance of Gilbert model traces the performance according to a combination of links between the objectives (targets, estimates, projections), the means to achieve them (human, material, financial or informational resources) and the results obtained (goods, products, services, etc.), (Figure $4)$.

Figure 4: Gilbert Performance Model (Gibert p 1980)

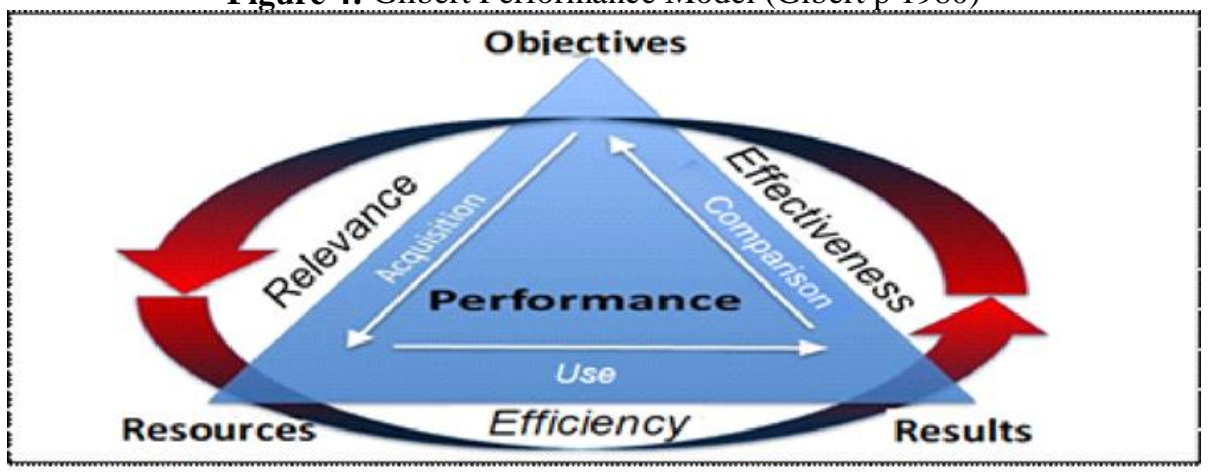

The performance measurement does not focus solely on the financial aspect. It combines a balanced system between financial and non-financial indicators, in the short or long term, between intermediate indicators and results measurement. This system is called the Balanced Score Card (BSC) or Balanced Scorecard. These indicators are divided into four axes (finances, clients, internal processes and organizational learning). These include financial performance, customers-defined performance and internal process performance (Kaplan and Norton, 2007). The different performances according to the BSC are linked by cause-and-effect relationships that shape strategy. The objective is to articulate the initiatives of employees, departments and the company, then identify using dynamic simulations, new processes to meet customer and shareholder expectation's (Kaplan and Norton, 2007), (Figure5). 
Figure 5: The Diagram showing the articulations of the 4 perspectives of the BSC centered on the strategy map (Kaplan and Norton 2007).

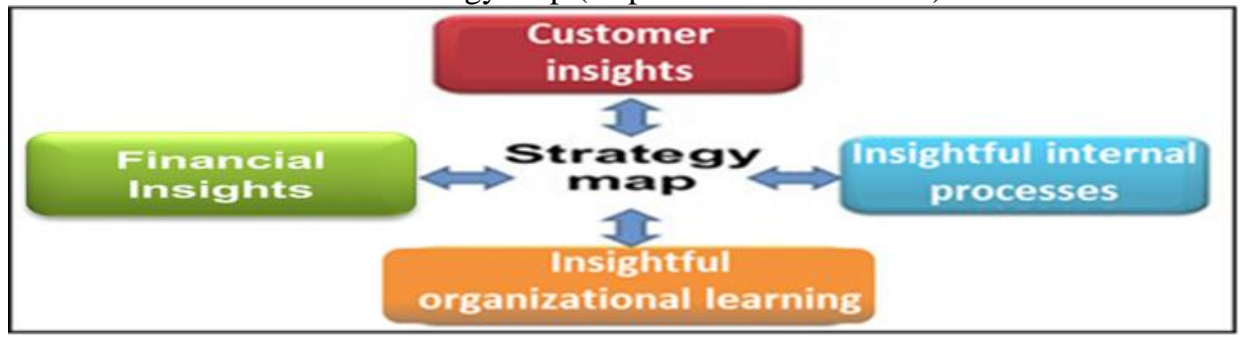

\section{II.4 Impact of quality approach on performance:}

According to the literature, there are some confusion and contradictions regarding the effectiveness of certification. The study done by Feng and al in 2008, based on 613 companies in the industrial and service sector in New Zealand, Australia, concluded that there is a positive and significant relationship between ISO certification and operational performance. However, the relationship between ISO 9001 certification and business performance was found positive, but weakly not significant. We conclude that the certification alone does not have a unique and direct positive impact on business performance. The success ISO implementation would be increased if it is well planned and when the philosophical aspects of the organization are coupled with employee training, periodic audits, corrective actions and commitment at all levels of the organization (Feng, Terziovski, and Samson 2008).

According to Terziovski and al.(2003), there is a significant and positive relationship between a leader's motivation to adopt ISO certification and business performance. The main motivation for adopting ISO certification is customer pressure. But, organizations that voluntarily adopt the certification approach are more likely to have improved organizational performance (Terziovski and al,2003). In the same context, Rolland and Tran confirm the same idea : if the process is voluntary from the general management and if it is not constrained, on the part of senior management; the ISO 9000 certification therefore appears to increase the company performance (Rolland and Tran, 2006).

Charlees and al, (2005) tracked the financial performance of certified industrial companies, from 1987 to 1997 , on the basis of more than 21,482 ISO 9001 certifications issued to the states in the sectors representing the largest number of certificates. By referring to focus groups of non-certified companies in the same industry and of the same size. They concluded that the certification leads to productivity improvements and financial performance. Similarly, by examining the effect of ISO 9001 certification on publicly traded companies, they realize that certification leads to improved financial 
performance. Specifically, they conclude that companies not having sought certification have experienced substantial deterioration in asset performance, productivity and sales. While certified companies have, in general, avoided such phenomena of economic decline and underperformance.

Also, the ISO 9001 effectiveness directly contributes to product quality and operational performance. Although it has no direct impact on manufacturing firms' business performance, it has an indirect impact through the moderator of operational performance (Kafetzopoulos et al., 2015). In addition, other companies that have certification; have not seen a positive change in their absolute performance, they have seen an improvement in their relative performance compared to their counterparts. A company needs other resources to improve, especially since ISO 9001 is an organizational "standard" and its implementation alone within a company is not a lasting competitive advantage. Therefore, other tools and resources must be put in place, which are more difficult to imitate and can constitute a differentiating competitive advantage. Paradoxically, not opting for ISO 9001 certification contributes to a gradual unfavorable evolution of performance (Rolland and Tran, 2006).

The analysis of 98 studies processed by Aurélie in 2007 on the impacts of the ISO 9001 standard, reveals that the implementation of the ISO 9001 standards has an impact on operational, quality, strategy and managerial management. While the most marked contingency factors in this standard are the initial motivation to adopt the approach (voluntary or binding), the involvement of managers and employees (Aurélie, 2007).

According to an empirical study carried out by Lambert and Ouedraogo on 85 industrial processes of certified companies in 2008, the authors reveal that ISO certification has a significant impact on knowledge creation and management. This study assumes that total quality and ISO 9001 have similar impacts on knowledge management (Lambert and Ouedraogo, 2008) Terzviovski and Guerrero demonstrated through a study carried out in 2014 on 220 companies in Australia that ISO 9000 certification statically does not have a significant impact on product innovation. Certified companies focus on product detail and overlook its innovation. However, this certification has a significantly positive impact on business process innovation (Terziovski and Guerrero, 2014). 
The table 2 summarize the different auteurs finding about relationship with quality approach and performance:

\begin{tabular}{|c|c|}
\hline Authors & Findings \\
\hline $\begin{array}{l}\text { Mei Feng, Mile' Terziovski and } \\
\text { Danny Samson, }(2008)\end{array}$ & $\begin{array}{l}\text { There is a positive and significant relationship } \\
\text { between quality practices: (implementation, } \\
\text { organizational commitment and planning) and } \\
\text { operational performance. }\end{array}$ \\
\hline Lassâad Lakhal (2006) & $\begin{array}{l}\text { There is a significant relationship between } \\
\text { management and infrastructure practices and } \\
\text { operational performance. }\end{array}$ \\
\hline $\begin{array}{l}\text { Terziovski, M., Power, D., \& Sohal, } \\
\text { A. S.(2003) }\end{array}$ & $\begin{array}{l}\text { There is a significant and positive relationship } \\
\text { between leader's motivation to adopt ISO certification } \\
\text { and business performance. }\end{array}$ \\
\hline $\begin{array}{l}\text { Charlees J. Corbett, María } \\
\text { Montes-Sancho, \& David A. } \\
\text { Kirsch, (2005) }\end{array}$ & $\begin{array}{l}\text { The certification leads to productivity improvements } \\
\text { and financial performance. } \\
\text { The companies not having sought certification have } \\
\text { experienced substantial deterioration in asset } \\
\text { performance, productivity and sales. }\end{array}$ \\
\hline $\begin{array}{l}\text { Kafetzopoulos, D. P., Psomas, E. L., } \\
\text { \& Gotzamani, K. D, (2015) }\end{array}$ & $\begin{array}{l}\text { It has no direct impact on manufacturing firms' } \\
\text { business performance, it has an indirect impact } \\
\text { through the moderator of operational performance. }\end{array}$ \\
\hline Lambert and Ouedraogo, (2008) & $\begin{array}{l}\text { ISO certification has a significant impact on } \\
\text { knowledge creation and management. }\end{array}$ \\
\hline Terziovski and Guerrero, (2014) & $\begin{array}{l}\text { ISO } 9000 \text { certification statically does not have a } \\
\text { significant impact on product innovation. }\end{array}$ \\
\hline $\begin{array}{l}\text { Pambreni, Y., Khatibi, A., Azam, } \\
\text { S., \& Tham, J, (2019) }\end{array}$ & $\begin{array}{l}\text { The customer focus, continuous improvement, } \\
\text { strategically based, and total employee involvement } \\
\text { have a positive and significant effect on organization } \\
\text { performance. }\end{array}$ \\
\hline Fonseca and Domingues, (2018) & $\begin{array}{l}\text { The principal reported benefits of quality practices are: } \\
\text { risk-based thinking, mapping of the organizational } \\
\text { context, and stakeholder identification }\end{array}$ \\
\hline Hale Kaynak, (2003) & $\begin{array}{l}\text { The quality practices: leadership; training; relationship } \\
\text { employee involvement; supplier Quality } \\
\text { Management; and process management, are an impact } \\
\text { on Inventory management performance; financial and } \\
\text { market performance. }\end{array}$ \\
\hline Prajogo, D. I., \& Sohal, A. S, (2003) & $\begin{array}{l}\text { The practice of: leadership; strategic planning; } \\
\text { customer focus; information and analysis; people } \\
\text { management and process management are } \\
\text { significantly and positively related to the product } \\
\text { quality and product innovation performance. }\end{array}$ \\
\hline $\begin{array}{l}\text { Reed, R., Lemak, D. J., \& Mero, N. } \\
\text { P. (2000) }\end{array}$ & $\begin{array}{l}\text { The practice of: Leadership; commitment; training } \\
\text { and awareness; teams and culture can generate a } \\
\text { sustainable competitive advantage. }\end{array}$ \\
\hline $\begin{array}{l}\text { Flynn, B. B., Schroeder, R. G., \& } \\
\text { Sakakibara, (1995) }\end{array}$ & $\begin{array}{l}\text { The top management support was found to be critical } \\
\text { to both infrastructure and core quality management } \\
\text { practice. }\end{array}$ \\
\hline
\end{tabular}


The type of relationship between quality management approach and its contributions to the company, sometimes seem contradictory. In some academic works, the link is positive; on the contrary, others demonstrate the non-existence of this link. So, there is some confusion and contradictions regarding the effectiveness of quality practices. For empirical work that demonstrates a positive link between quality approach and performance, the literature review highlights the lack of consensus in the work on the impact of quality practice on performance. Although several studies point to the positive effects of quality practice, they also indicate that certain factors appear necessary for the link to work. This link between quality practices and the organization's performance can guide decision-makers in their choice to engage in such a process. The first motivation for adopting the quality approach, significantly influences the achievement of the performance desired by the company when the motivation is voluntary without any external pressure. The types of performance most affected in most studies are the organizational performance, which include: financial performance and operational performance.

\section{Conceptual Model of the study and hypotheses development:}

Based on the results of this literature review, the choice of our conceptual model will revolve around quality management practices and their impact on performance. Since these practices are very varied in the literature, their choices vary from one search to another, depending on the research purpose. In the case of our model and by referring to this literature review, we have established four quality practices: Leadership, customer focus; staff Involvement; Continuous improvement, which seem to us the most repeated in the literature ((Feng, Terziovski and Samson,2008); (Pambreni et al., 2019); (Flynn et al., 1995); (Fonseca and Domingues, 2018); (Prajogo \& Sohal, 2003); (Reed et al., 2000); (Hale Kaynak ; 2003)), and meet the quality management principles.

For performance measurement, we opted for The Balanced Scorecard which aims to measure a company's activities according to two types of performance; financial performance and operational performance(Kaplan \& Norton, 1996). The financial performance presents the financial health of the organization and includes indicators: Return on capital; Cash flow; Project suitability and value of order books. The axes of operational performance include; customer axes which take into account customer satisfaction and needs and internal processes which look for efficiency, providing competitive advantages and learning effects and human resources management. 
Our research hypotheses can be read as follows:

H1 : Leadership has a positive impact on operational performance.

$\mathrm{H} 2$ : Leadership has a positive impact on financial performance.

$\mathrm{H} 3$ : Customer focus has a positive impact on operational performance.

H4 : Customer focus has a positive impact on financial performance.

H5 : Staff Involvement has a positive impact on operational performance.

H6 : Staff Involvement has a positive impact on financial performance.

$\mathrm{H} 7$ : Continuous improvement has a positive impact on operational performance.

$\mathrm{H} 8$ : Continuous improvement has a positive impact on financial performance.

Therefore, our research model will allow the investigation of the impact of quality practice on financial and operational performance (Figure 6). This model will be applied through an exploratory study in the case of Moroccan companies.

Figure 6: conceptual models according to the literature review

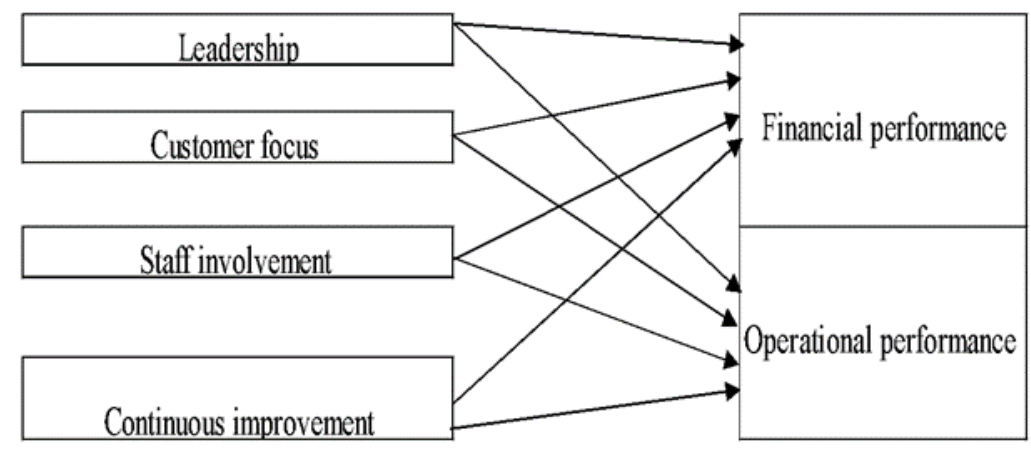

\section{Conclusion and research perspective:}

The literature review highlights the lack of consensus in works related to the impact of certification on performance. Although several studies point to the positive effects of certification, they indicate that certain factors appear necessary for the link to work. This link between certification and the performance can guide decision-makers in their choice to engage in such a process.

The purpose of this article is to develop a research model on the relationship between quality approach and organization performance. Indeed, we point out that this model represents only the basis, and it is only a preliminary step towards understanding the problem posed. Further research is needed to modify and integrate other variables into the basic model. In addition, empirical work dealing with the case of Morocco will soon be 
established, through a data collection study that is underway to serve as a test of the research model using econometric modeling.

\section{References:}

1. Aurélie, M. (2007). les impacts organisationnels de la norme ISO 9000 : Une revue systématique de la littérature.

2. Brandenburg, H., \& Wojtyna, J.-P. (2003). L'approche processus : Mode d'emploi. Ed. d'Organisation.

3. Chaminade,B. (2005). Chaminade, B. (2005). RH \& compétences dans une démarche qualité.

4. Charlees J. Corbett, María J. Montes-Sancho, \& David A. Kirsch. (2005). The Financial Impact of ISO.

5. Deming, W. E., \& Edwards, D. W. (1982). Quality, productivity, and competitive position (Vol. 183). Massachusetts Institute of Technology, Center for advanced engineering study.

6. Dumez, H. (2011). Faire une revue de littérature: Pourquoi et comment?

7. Feng, M., Terziovski, M., \& Samson, D. (2008). Relationship of ISO 9001 : 2000 quality system certification with operational and business performance. Journal of manufacturing technology management.

8. Flynn, B. B., Schroeder, R. G., \& Sakakibara, S. (1995). The impact of quality management practices on performance and competitive advantage. Decision sciences, 26(5), 659-691.

9. Fonseca, L. M., \& Domingues, J. P. (2018). Empirical Research of the ISO 9001:2015 Transition Process in Portugal: Motivations, Benefits, and Success Factors. Quality Innovation Prosperity, 22(2), 16. https://doi.org/10.12776/qip.v22i2.1099

10. ISO - A propos de l'ISO. (s. d.). ISO. Consulté 16 février 2020, à l'adresse https://www.iso.org/fr/about-us.html

11. ISO 1005. (2005). ISO 10005:2005(fr), Systèmes de management de la qualité-Lignes directrices pour les plans qualité. https://www.iso.org/obp/ui/\#iso:std:iso:10005:ed-2:v1:fr

12. ISO 9001-2015.pdf. (s. d.).

13. ISO 10018:2012(fr),(2012).

14. ISO,(2016).Principes de management de la qualité (Organisation internationale de normalisation; Secrétariat central de l'ISO; iso.org (C) ISO, 2016 ISBN 978-92-67-20650-9.

15. https://www.iso.org/obp/ui/\#iso:std:iso:10018:ed-1:v1:fr

16. Juran, J., \& Godfrey, A. B. (1999). Quality handbook. Republished McGraw-Hill, 173(8).

17. Kafetzopoulos, D. P., Psomas, E. L., \& Gotzamani, K. D. (2015). The impact of quality management systems on the performance of 
manufacturing firms. International Journal of Quality \& Reliability Management, 32(4), 381-399. https://doi.org/10.1108/IJQRM-112013-0186

18. Kaplan, R. S., \& Norton, D. P. (1996). Using the balanced scorecard as a strategic management system. Harvard Business Press.

19. Kaplan, R. S., \& Norton, D. P. (2007). Balanced scorecard. In Das Summa Summarum des Management (p. 137-148). Springer.

20. Kaynak, H. (2003). The relationship between total quality management practices and their effects on firm performance. Journal of operations management, 21(4), 405-435.

21. Lakhal, L., Pasin, F., \& Limam, M. (2006). Quality management practices and their impact on performance. International Journal of Quality \& Reliability Management.

22. Lambert, G., \& Ouedraogo, N. (2008). Empirical investigation of ISO 9001 quality management systems' impact on organisational learning and process performances. Total Quality Management \& Business Excellence, 19(10), 1071-1085.

23. Maxwell, J. C. (2006). Developing the leader within you. Thomas Nelson; New Holland [distributor.

24. Maxwell, J. C. (2011). The 5 levels of leadership: Proven steps to maximize your potential. Center Street.

25. Mercier, S. (2006). 9. La théorie des parties prenantes: Une synthèse de la littérature. In Décider avec les parties prenantes (p. 157-172). La Découverte; Cairn.info. https://www.cairn.info/decider-avec-lesparties-prenantes--9782707147844-p-157.htm

26. Pambreni, Y., Khatibi, A., Azam, S., \& Tham, J. (2019). The influence of total quality management toward organization performance. Management Science Letters, 9(9), 1397-1406.

27. Patyal, V. S., \& Koilakuntla, M. (2017). The impact of quality management practices on performance: An empirical study. Benchmarking: An International.

28. Pekovic, S., \& Rolland, S. (2012). L'impact de I'orientation client sur la performance des entreprises françaises : Étude empirique des effets directs et modérateurs. Recherche et Applications en Marketing (French Edition), 27(4), 11-38.

29. Pesqueux, Y. (2004). La notion de performance globale.

30. Prajogo, D. I., \& Sohal, A. S. (2003). The relationship between TQM practices, quality performance, and innovation performance. International journal of quality \& reliability management.

31. Qualitiso. (2014, novembre 20). Les 7 principes de management de la qualité. Qualitiso. https://www.qualitiso.com/7-principesmanagement-qualite/ 
32. Reed, R., Lemak, D. J., \& Mero, N. P. (2000). Total quality management and sustainable competitive advantage. Journal of quality management, 5(1), 5-26.

33. Rolland, S., \& Tran, S. (2006). La certification qualité est-elle un facteur de compétitivité pour les entreprises? Le cas de la norme ISO 9001.

34. Terziovski, M., \& Guerrero, J.-L. (2014). ISO 9000 quality system certification and its impact on product and process innovation performance. International Journal of Production Economics, 158, 197-207.

35. Terziovski, M., Power, D., \& Sohal, A. S. (2003). The longitudinal effects of the ISO 9000 certification process on business performance. European Journal of operational research, 146(3), 580-595. 